IZA DP No. 6625

The Unexpected Appearance of a New German Model

Werner Eichhorst

June 2012 


\title{
The Unexpected Appearance of a New German Model
}

\author{
Werner Eichhorst \\ IZA
}

\author{
Discussion Paper No. 6625 \\ June 2012
}

\author{
IZA \\ P.O. Box 7240 \\ 53072 Bonn \\ Germany \\ Phone: +49-228-3894-0 \\ Fax: +49-228-3894-180 \\ E-mail: iza@iza.org
}

\begin{abstract}
Any opinions expressed here are those of the author(s) and not those of IZA. Research published in this series may include views on policy, but the institute itself takes no institutional policy positions.

The Institute for the Study of Labor (IZA) in Bonn is a local and virtual international research center and a place of communication between science, politics and business. IZA is an independent nonprofit organization supported by Deutsche Post Foundation. The center is associated with the University of Bonn and offers a stimulating research environment through its international network, workshops and conferences, data service, project support, research visits and doctoral program. IZA engages in (i) original and internationally competitive research in all fields of labor economics, (ii) development of policy concepts, and (iii) dissemination of research results and concepts to the interested public.
\end{abstract}

IZA Discussion Papers often represent preliminary work and are circulated to encourage discussion. Citation of such a paper should account for its provisional character. A revised version may be available directly from the author. 


\section{ABSTRACT}

\section{The Unexpected Appearance of a New German Model}

Most Continental European labour markets and welfare states underwent a substantial transformation over the last two decades moving from a situation of low employment and limited labour market inequality to higher employment, but also more inequality. Germany is a case in point as it exhibits growing employment figures and growing shares of low pay and non-standard work. Furthermore, the German labour market has been remarkably resilient during the recent crisis. How can this be explained? The paper claims that changes in labour market institutions such as unemployment benefits, active labour market policies and employment protection play a major role, but changes in industrial relations at the sectoral level and individual firms' staffing practices are equally important in explaining actual labour market outcomes. Regarding labour market institutions, the pattern found in Germany shows sequences of de- and re-regulatory reforms of employment protection and increasing or decreasing unemployment benefit generosity, both mostly addressing the margins of the labour market, i.e. 'outsiders', and contributing to a growing dualisation of the employment system. The institutional status of 'insiders' was hardly affected by legislative changes. This dualisation trend was reinforced by micro-level dynamics in industrial relations and company employment practices where we can observe growing reliance on mechanisms of internal flexibility for the skilled core work force and increasing use of non-standard types of employment in less specifically skilled occupations.

JEL Classification: J21, J31, J52, J68

Keywords: Germany, employment growth, labor market reforms, dualisation, flexibility

Corresponding author:

Werner Eichhorst

IZA

P.O. Box 7240

53072 Bonn

Germany

E-mail: eichhorst@iza.org 


\section{Introduction}

After some decades of mainly negative perception both from within Germany and abroad, the German employment 'model' is attracting quite some attention again. This is mainly due to its apparent success in weathering the recent global economic crisis without encountering major job loss, but, in contrast, exhibiting decreasing unemployment rates and record levels of jobs created (Rinne and Zimmermann 2011). In fact, after a long period of stagnation, Germany has now one of the highest employment rates in Continental European countries and is no longer far behind countries such as Denmark and Sweden or the Netherlands and basically in line with the UK as Figure 1 shows. Unemployment has also been decreasing significantly in Germany over the last years (Figure 2). Quite unexpectedly, as it was often seen as a laggard with a persistent weakness in job creation, Germany is now on par with former role model or benchmark countries. Furthermore, accelerated job creation in Germany cannot only be attributed to the emergence of an additional layer of 'bad jobs' at the margin of the labour market due to deregulation, but it is also partly driven by structural changes encouraging the creation of many 'good jobs' in skilled service sector occupations. However, the recent change in labour market conditions did not come over night, and it is not sufficient to focus only on the remarkably good performance during the crisis, but, as this article shows, the overall improvement in labour market outcomes is the effect of a longer sequence of cumulative structural and institutional adjustment revitalising some of Germany's traditional strengths and adding some new elements. Furthermore, what is quite remarkable, is the fact that most of these adjustments were rather non-strategic, but short-termist, not relying on systematic economy-wide coordination but rather small steps of adjustment both in the sphere of employers' staffing policies and collective bargaining as well as in public labour market policies and regulation. 
Figure 1: Employment/population ratios in selected countries, 1995-2010

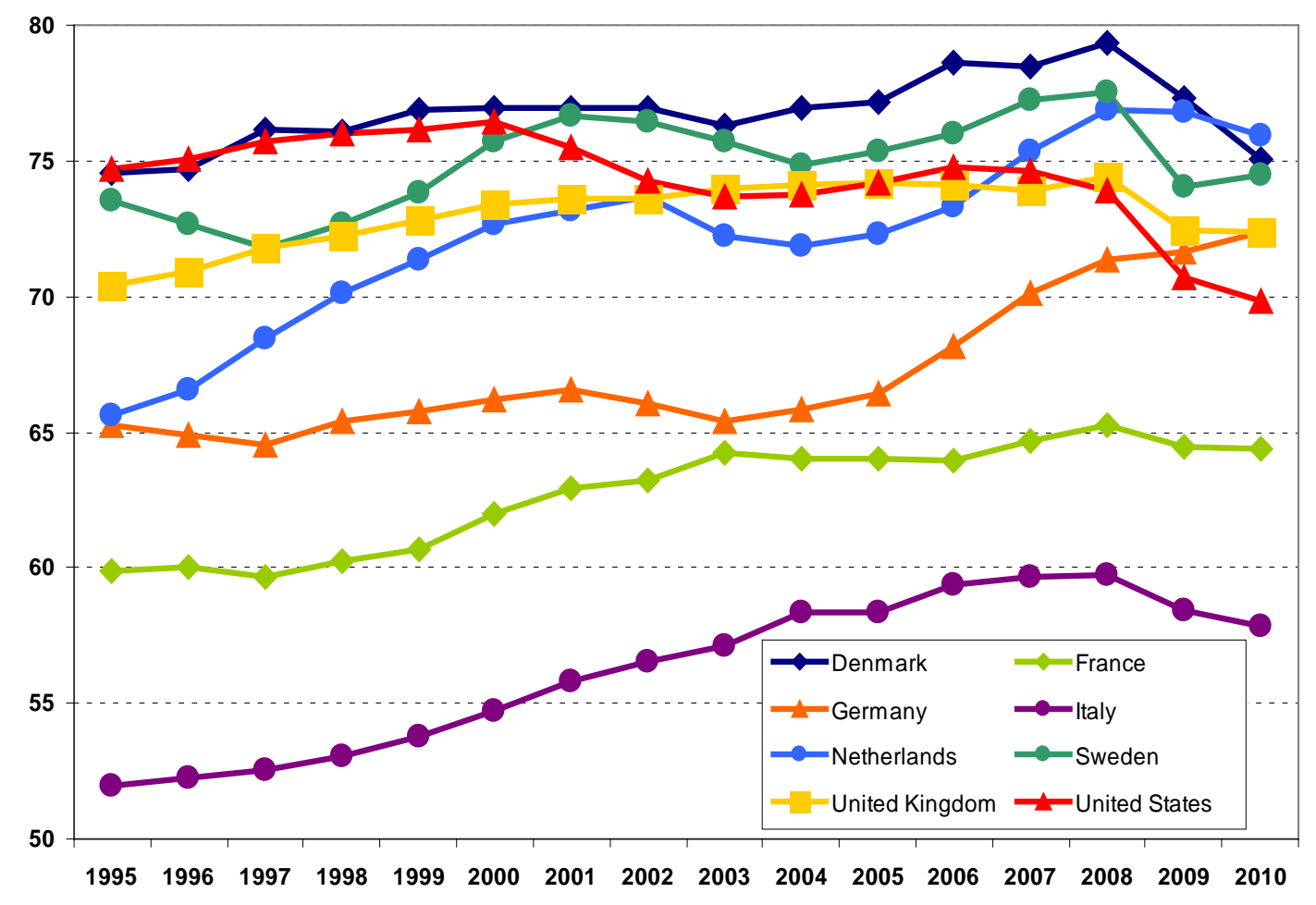

Source: OECD. 
Figure 2: Unemployment rates in selected countries, 1995-2011

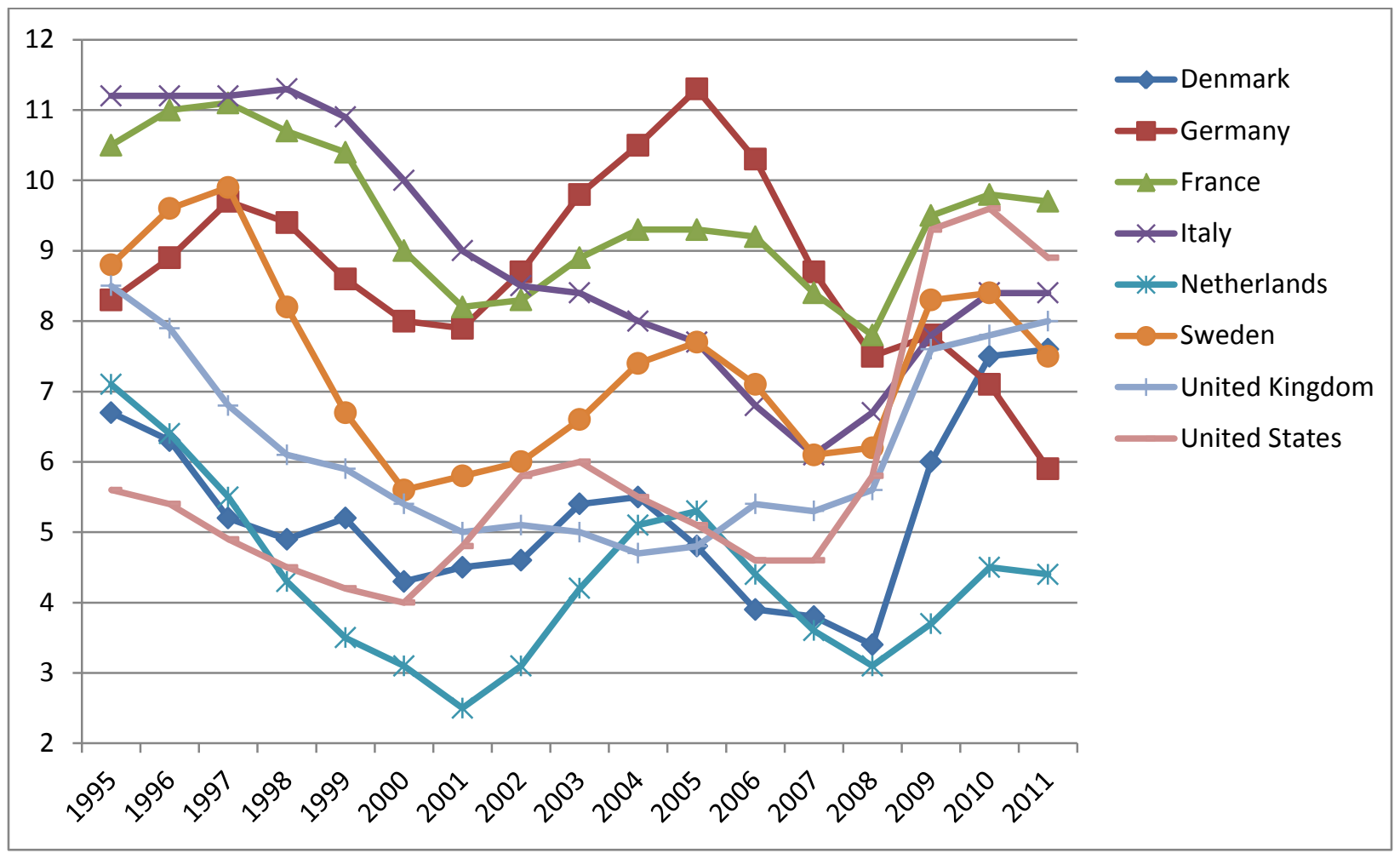

Source: Eurostat.

\section{Explaining change: Some conceptual issues}

While for a long time Continental European labour markets were described as sclerotic and suffering from persistent lack of employment opportunities (Scharpf 2000, Manow and Seils 2000), fundamental institutional change is now widely acknowledged (see Palier 2010, Hemerijck and Eichhorst 2010). This strand of literature puts major emphasis on the role of sequences of politically induced institutional change within welfare states and labour market arrangements while others have focused on the disorganisation decay of the institutional core of the German labour market, in particular industrial relations in manufacturing (Streeck 2009).

Prominent recent contributions also emphasize the need to take into account agency below the level of formal institutional reforms at the national level and point at mechanisms of change relying on actors' practical use and redefinition of institutional provisions (Streeck and Thelen 2005). This is an essential extension of usual institutionalist explanations as it allows for the recognition of patterns of adjustment that rely on second-best solutions developed by actors faced with massive restrictions and only limited opportunities for systematic change along their preferences. This can be interpreted as a strategy of 'satisficing', and due to its short-term orientation long-term consequences might be different than expected and oftentimes unintended. Protracted sequences of partial, but cumulative change at the national or sectoral 
level - in combination with market actors' micro-level decisions - can lead to a reconfiguration of the institutional framework. At a certain point, this can result in a 'good fit' between institutions, policies and the economic environment so that the performance of the overall arrangement increases. As Scharpf (1991) has already pointed out, institutional settings and public policies work best if they fit with the economic constellation. However, this also implies that a 'good fit' between the institutional setting and the economic environment may not last but pave the way for further adjustment, given continuous socio-economic change. In general, as this paper argues, understanding the current German success, compared to the past and to other countries, requires a longer time horizon which does not only focus on the last decade and the aftermath of the labour market reforms of the mid-2000s that received a lot of political and academic attention both within Germany and from abroad.

Furthermore, this article claims that labour market developments cannot be explained properly by analysing just the institutional change induced by government and, to some extent, the social partners. But this can only be achieved by taking into account the interplay of institutional change at the legislative level, industrial relations, and organisational, in particular human resource practices at the company level. Market actors' behaviour at the micro level is seen as an important factor here. The claim is that actual labour market outcomes and employment patterns are best understood as an interaction between institutional provisions set by policy makers and micro-economic adaptation of employers, employees (and jobseekers) - this also means that actual outcomes of 'big' institutional reforms can only be predicted partially as they do not fully determine actors' behaviour. Labour market structures can also change without institutional change as such just by autonomous change of actors' strategies in response to economic conditions such as the competitive environment, changes in labour demand for certain productive activities and available labour supply. That also implies that policy makers do not have full control over concrete adaptive processes as all public policies and reforms entail some uncertainty regarding their actual impact. For politico-economic reasons far-reaching reforms are virtually impossible.

To overcome this dilemma, policy makers opt for partial, incremental or marginal adaptation which often tends to create ambiguous institutional arrangements leading to unintended consequences. Employers (and employees as well as job seekers) also have only limited room to manoeuvre regarding employment conditions. So limited capacities to act and change the terms of trade of employment make searching for and pursuing second-best solutions a pragmatic strategy both for policy makers and labour market actors. With respect to labour market change, the claim is made that it can only be understood by taking into account the restructuring of companies' staffing policies which redraw company boundaries and margins between different categories of workers within the framework set by institutions. Through the interactive process of change at different levels a high degree of labour market flexibility could be achieved without openly challenging the institutional core. While employers, plant-level and sectoral social partners are core actors in restructuring internally, government has a major role in non-standard contracts, but take-up of these employment options depends on the decisions of both employers and employees or job seekers under certain economic conditions.

The paper also claims that, in order to understand the reconfiguration of the German labour market, observers need to take the logic of service sector job creation seriously. Many 
contributions still focus on manufacturing and industrial relations in this sector which is still seen as the core of the German economic model (and is certainly still relevant), but they tend to neglect the autonomous and divergent logic of services (see Streeck 2009, Hassel 2011, Carlin and Soskice 2009). Contributions stressing the role of industrial relations in the manufacturing sector, in particular wage and working time flexibility and functional adaptation of skilled workers, often to underrate the quite distinct logic of service employment which is crucial when it comes to explaining job growth in recent years. The literature referring to 'varieties of capitalism' sees services mainly as inputs for manufacturing so that producer coalitions dominated by manufacturing employers and trade unions are assumed to advocate labour cheapening and deregulatory policies addressing the service sector (Hassel 2011). However, at least in the German case there is no clear evidence of a producer coalition based in manufacturing pushing for labour market reforms cheapening labour in service sector occupations. In fact, the service sector cannot be seen as an appendix of manufacturing or mainly as a supplier of inputs for manufacturing. Hence, there are no signs for a clear preference of core actors for liberalization at the margin in the sense that service sector work has to be made cheaper of more flexible mainly for manufacturing purposes (Hassel 2011, Carlin and Soskice 2009). In fact, as will be shown in this paper, services related to or outsourced from manufacturing are only one element, and not necessarily the cheapest one. Most of the service sector occupations are quite remote from manufacturing. And deregulation of non-standard work, which is particularly important for some service sector occupations, was mainly motivated by job creation purposes.

\section{Two decades of restructuring}

In a stylised fashion, Germany is often taken as a model of labour market flexibility that, due to its elaborate training system and working time arrangements, is focused around internal numerical and functional flexibility and a very limited amount of external and wage flexibility (see e.g. Eichhorst, Marx and Tobsch 2009). However, this gives only a very general picture. To better understand the restructuring of the German labour market one has to go beyond these stylised facts and adopt a sectoral perspective. While it is still true that manufacturing exhibits high levels of internal flexibility, external and wage flexibility has grown there. On the other hand, the service sector is certainly characterised by higher levels of external flexibility, but yet, this is also not the full story as there is also remarkable heterogeneity. The current appraisal of the (reinvented) German employment model can be seen as a - more or less - unplanned result of a protracted sequence of adjustments mainly driven by short-time considerations regarding the aim of raising employment and reducing unemployment and social expenditure on the side of the governments - promoting non-standard jobs in particular (Eichhorst and Marx 2011) and competitiveness objectives of employers.

\subsection{MANUFACTURING}

Manufacturing can still be taken as the backbone of the German economy although it is only directly responsible for about one quarter of all jobs in Germany (see Figure 3). German 
manufacturing underwent a process of modernisation that had consequences both for the core labour force and for the relations between core and margin. Of course, occupation- and to some extent also firm-specific skills are required for the competitive and innovative production of export goods which are Germany's specialisation in international trade.

Figure 3: Employment by sector in Germany, 1,000s, 1995-20011

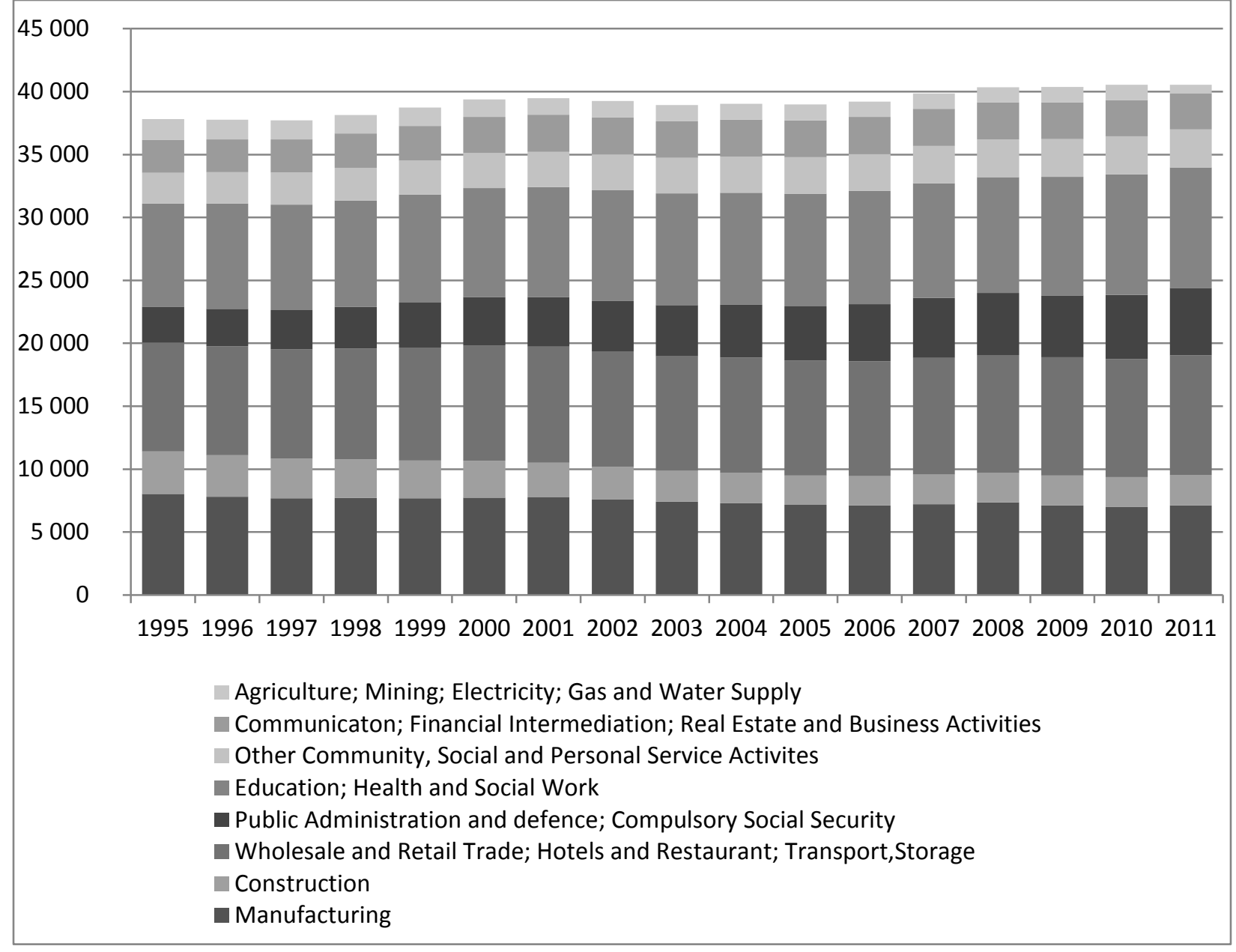

Source: Council of Economic Advisors. 
Substantial restructuring in the German metal working sector - the core sector in term of economic significance and institutional innovation - in the 1980s and 1990s was triggered by trade union initiatives towards working time reduction eventually leading to a fundamental agreement on a shortened working in the Western part of the country in exchange for increased internal flexibility. In an environment characterised by deeper global economic integration and competition, employers insisted on making working time much more flexible to avoid strict overtime rules and increase productivity (Trinczek 1998). Furthermore, in particular in the difficult phase of the 1990s, competitive pressure led to stronger concession bargaining resulting in a long phase of wage moderation and increasing wage and working time flexibility within collective agreements via so-called opening clauses allowing for plant-level derogation (Rehder 2003). The main objective of employers was to regain competitiveness, and trade unions and works councils were mostly interested in safeguarding existing jobs for their core constituencies as those workers would have faced major difficulties in finding equally attractive jobs elsewhere, e.g. in services. As a consequence, the plant level gained in importance for concession bargaining, and internal cooperation between management and works councils representing the core labour force was rather strengthened than weakened. In return, trade unions and, in particular, works councils were compensated by time-limited employment guarantees. Plant-level flexibility increased and led to more adaptable reconfigurations of sectoral collective bargaining later on.

Sectoral social partners were weakened, however, as both trade union membership and the propensity of employers to organize themselves in traditional associations declined as some firms left these associations and new firms did not enter, in particular in Eastern Germany. New types of associations without bargaining mandate emerged. At the same time, however, subcontracting to specialist suppliers became more prominent, both in the domestic and the global context. Outsourcing first to Eastern Europe and later on to non-European countries was the trend of the time (Sachverständigenrat für die Begutachtung der gesamtwirtschaftlichen Entwicklung 2004, Grömling and Matthes 2010), therefore concentrating the value added in core companies on more advanced parts of the value chain and increasing the share of inputs bought from suppliers. This allowed manufacturing employers to maintain stable, but smaller core work forces. All in all, restructuring of manufacturing was less influenced by government and major public policy initiatives but by collective and plant-level bargaining. Through this combination of more radical outsourcing and expanding internal flexibility skilled core workers could maintain their jobs with relatively favourable working conditions while employers' priority was to restore competitiveness, which had to rely on a stable and motivated core work force with specific skills. But work in Germany had to become more productive and flexible in order to contain unit labour costs. This was achieved by productivity-enhancing reorganisation and more price-competitive supply chains.

It is remarkable that different forms of non-standard employment such as fixed-term employment only had minor importance for the manufacturing sector despite progressively liberalising reforms at the margin of the labour market implemented since the mid-1980s that contributed to the increased frequency of 'atpyical' jobs (see Figure 4 and Table 1 below). The core of the German labour market, manufacturing, is still characterized by above-average levels 
of standard (full-time) employment and a remarkably high rate of conversion of both apprenticeship and fixed-term contracts into permanent ones (Bellmann, Fischer and Hohendanner 2009). Compared to other sectors, jobs in the metal working sector continue to be characterized by standard open-ended contracts with above-average pay - although internal flexibility and wage moderation changed parameters substantially. In German manufacturing, the availability of fixed-term contracts as one employment option did not add much benefits due to specific skills Institutional stability regarding legislative provisions dominates, but significant change occurred within collective bargaining and company policies.

Figure 4: Different forms of employment in Germany, 1996-2010 (1996 = 100)

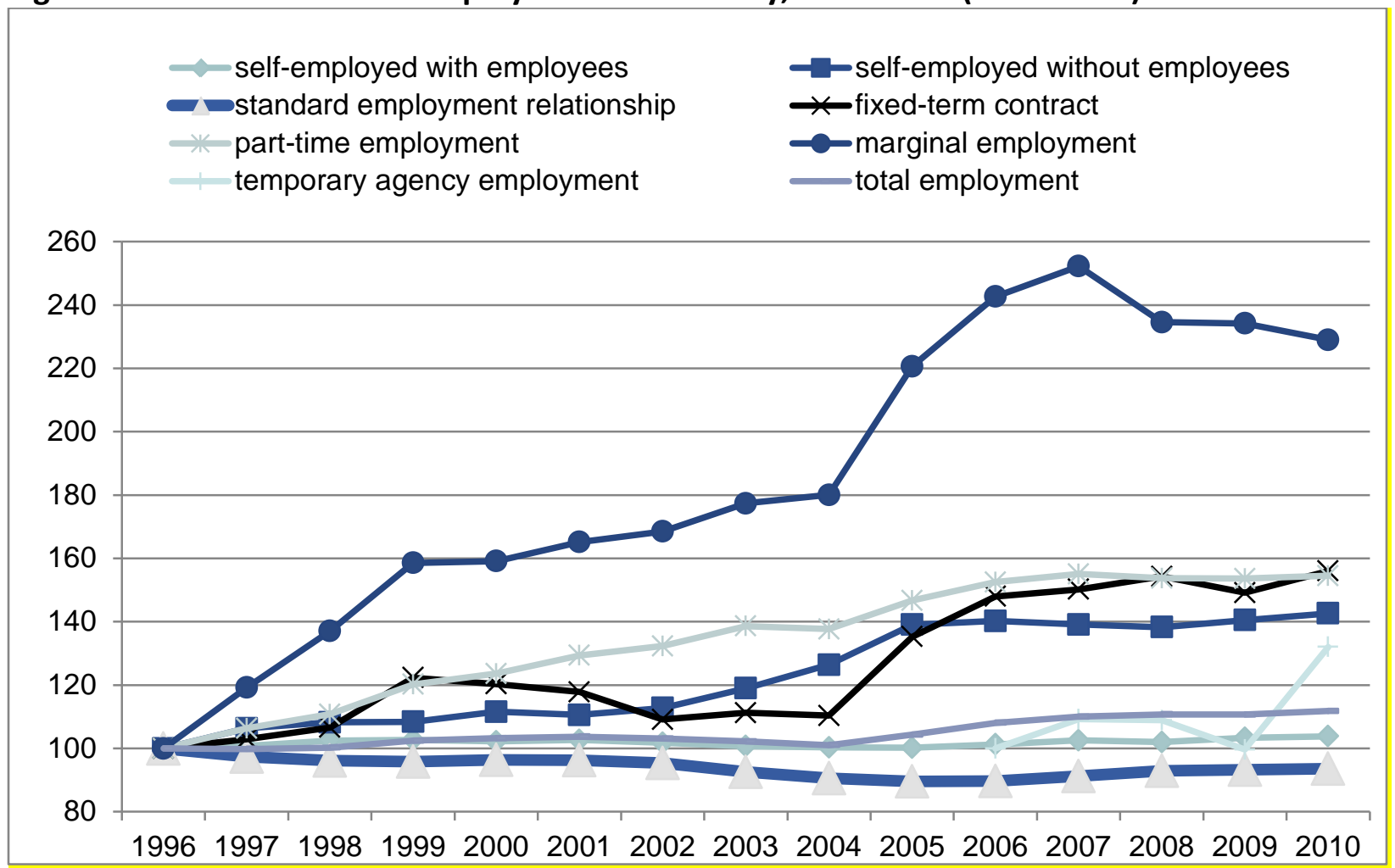

Source: Federal Statistical Office. 
Table 1: Shares of different types of employment by sector in \%, 2010

\begin{tabular}{|c|c|c|c|c|c|c|c|}
\hline & 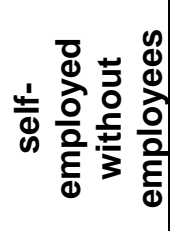 & 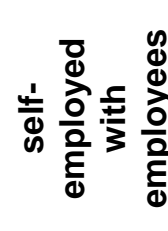 & 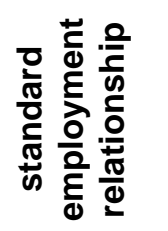 & 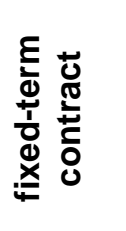 & 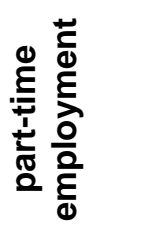 & 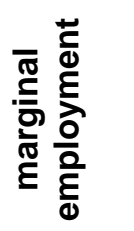 & 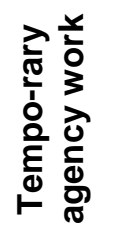 \\
\hline Private households & 5.8 & 0.5 & 12.5 & 4.8 & 65.4 & 51.0 & 0.0 \\
\hline $\begin{array}{l}\text { Other economic } \\
\text { activities }\end{array}$ & 6.9 & 4.5 & 42.6 & 14.1 & 21.6 & 14.7 & 10.6 \\
\hline Agriculture and forestry & 21.0 & 13.3 & 30.1 & 4.7 & 6.0 & 4.9 & 0.0 \\
\hline $\begin{array}{l}\text { Accommodation and } \\
\text { food service activities }\end{array}$ & 4.2 & 10.5 & 39.1 & 8.8 & 21.7 & 15.3 & 0.9 \\
\hline $\begin{array}{l}\text { Arts, entertainment and } \\
\text { recreation activities; } \\
\text { other services }\end{array}$ & 17.7 & 5.7 & 38.9 & 9.0 & 17.4 & 10.8 & 0.8 \\
\hline $\begin{array}{l}\text { Professional, scientific } \\
\text { and technical activities }\end{array}$ & 16.8 & 10.6 & 45.3 & 4.9 & 10.3 & 3.8 & 0.6 \\
\hline $\begin{array}{l}\text { Human health and } \\
\text { social work activities }\end{array}$ & 3.6 & 4.5 & 53.7 & 10.1 & 18.5 & 7.6 & 0.6 \\
\hline $\begin{array}{l}\text { Wholesale and retail } \\
\text { trade; repair of motor } \\
\text { vehicles }\end{array}$ & 5.0 & 5.7 & 54.3 & 6.2 & 17.6 & 9.6 & 1.1 \\
\hline Education & 4.9 & 0.8 & 56.6 & 12.9 & 15.0 & 4.5 & 0.5 \\
\hline $\begin{array}{l}\text { Information and } \\
\text { communication } \\
\text { activities }\end{array}$ & 10.7 & 3.3 & 59.2 & 5.2 & 8.7 & 4.9 & 0.8 \\
\hline Construction & 8.7 & 9.0 & 61.2 & 4.3 & 6.2 & 3.4 & 1.4 \\
\hline $\begin{array}{l}\text { Financial and insurance } \\
\text { activities; real estate } \\
\text { activities }\end{array}$ & 7.7 & 4.9 & 64.5 & 3.0 & 11.3 & 3.3 & 1.3 \\
\hline Real estate activities & 2.0 & 2.2 & 49.2 & 4.9 & 7.2 & 3.9 & 1.2 \\
\hline Mining and quarrying & 1.4 & 2.2 & 75.6 & 4.9 & 5.6 & 3.1 & 3.2 \\
\hline $\begin{array}{l}\text { Energy, water, waste } \\
\text { management }\end{array}$ & 1.4 & 1.1 & 78.1 & 6.1 & 3.7 & 1.8 & 4.8 \\
\hline $\begin{array}{l}\text { Public administration, } \\
\text { defense, social security }\end{array}$ & 0.0 & 0.0 & 73.3 & 5.9 & 8.3 & 2.2 & 0.5 \\
\hline
\end{tabular}

Source: Federal Statistical Office. 
The most notable exception from the resilience of standard employment in this sector is temporary agency work which has become a major form of highly flexible and low-paid work in routine occupations, mostly in manufacturing, but also in some areas of services. Temporary agency work provides an additional flexibility buffer for companies and their core work force in times of economic uncertainty. Furthermore, a considerable wage gap between direct employees and agency staff even for comparable jobs makes companies more competitive on the labour cost side - and tends to moderate wage claims of core workers. While in earlier phases, virtually all workers in German manufacturing were integrated in sectoral collective agreements due to direct employment relationships with firms and collective agreements (Köhler and Preisenberger 1988, Köhler and Sengenberger 1983), agency work now brings in a different category of employers adhering to specific collective agreements (Spermann 2011, Holst, Nachtwey and Dörre 2009, Baumgarten et al. 2012). As agency workers work side by side with directly employed workers in the same firm one can see this phenomenon as some kind of 'internal outsourcing'.

This new role of agency work is one of the most important direct consequences of the Hartz package and related labour market reforms with respect to the industrial sector. In 2002, the Hartz Commission saw agency work as the silver bullet to facilitate labour market integration of low-skilled and long-term unemployed, which were activated by stricter monitoring and some cuts in benefits (Eichhorst, Grienberger-Zingerle and Konle-Seidl, 2008) by providing them with real labour market experience - without encountering the need for heavy subsidisation or large-scale training. Hence, the Hartz reforms removed most restraints on agency work in Germany. In parallel, the principle of equal pay of agency workers and comparable direct employees of user companies was established - with only two options to deviate: first, in case of new hirings of unemployed people, and second, and most importantly, if collective agreements for the agency work sector set specific wages. This reform package was seen as a major achievement of the trade unions at the time as it allowed them to expand collective bargaining to this sector. But subsequent negotiations between different trade unions (DGB affiliates and Christian unions) and a number of associations of agency work firms (organising mostly larger or smaller companies, respectively) led to wage scales significantly below sectoral wages of manufacturing (and many service sector occupations). Agency workers were to be paid according to collectively agreed wages not of user companies such as metal working firms but in line with the wage scale of the agency work sector. Hence, there is a considerable wage gap between agency workers and regular staff amounting to 25 to 30 per cent on average. Taking into account the management fees and mark-ups of the temporary agency firms, gross hourly labour costs of agency workers faced by user companies tend to correspond to those of directly employed workers in German manufacturing. Yet, given the large share of workers with standard employment relationships, i.e. open-ended contracts with full statutory dismissal protection, manufacturing employers are willing to pay an extra fee to achieve additional external flexibility by using agency work.

Not surprisingly, metal working has become one of the strongest used branches of agency work. The least skill-intensive occupations where workers are most replaceable were assigned 
to the agency segment where employers benefit from external flexibility and labour cost advantages. Recent data show that about 4 per cent of total metal working staff is employed as agency workers. However, in low-skilled routine occupations such as labourers some companies employ much larger shares of agency staff reaching 30 to 50 per cent in some firms, in particular medium-sized and larger firms. Hence, in contrast to earlier phases of employment restructuring, low- and medium-skilled workers who would have been integrated into sectoral collective bargaining scale are now treated differently whereas standard employment relationship with high internal flexibility regarding working time and wages is still dominant for core staff. Regarding the relation between flexible and permanent staff, one can argue that the flexible marginal work force helps stabilize the core work force in time of business cycle volatility and crisis as can be seen from the most recent economic crisis. In combination with the newly created opportunity to assign workers to user companies for an indeterminate duration this established a new form of secondary segment in the manufacturing sector where specific skills do not matter and long-term employment is not asset but external flexibility and some labour cost advantage. Quite in contrast to the expectations regarding the stepping stone effect of agency work, recent studies could only find very limited mobility to direct employment by user companies (Baumgarten et al. 2012, Lehmer and Ziegler 2010).

Hence, regarding manufacturing, the institutional setup has been adjusted, but the role of government was quite limited as most adaptation occurred via collective bargaining and negotiations at the company level as well as by companies' organisational decisions. Due to this process of adjustment, manufacturing in Germany is still more important in terms of employment figures than in most other European countries. And manufacturing employment has been remarkably resilient over the last years.

In fact, Germany was the only country to show declining unemployment and increasing employment during the 2008-09 economic crisis. It is certainly most well-known for its shorttime work arrangement which contributed to a remarkable stabilization of manufacturing employment during the crisis which had not been completely predictable by earlier experiences and institutional preconditions. Certainly, political action was of some importance, in particular the extension of the maximum duration of short-time work allowance from 6 to 24 months and an increase in the maximum support available to employers - in contrast to the situation until fall 2008, employers were entitled to a full compensation of social security contributions for hours not worked starting from the sixth month of short-time work and from the beginning if training was provided.

Yet, policy reforms regarding short-time work were only one element of internal adjustment. In fact, most of the adjustment via working time reduction occurred at the company level via shorter working time, in particular reduced overtime work, and by eating up surpluses on working time accounts. This could be implemented without further institutional change. All in all, the smooth development of employment figures in German manufacturing was quite unexpected by most observers given the continuity of existing institutional arrangements. Only a change in employers' behaviour can explain that. German manufacturing employers acted very cautiously during the crisis. Past experience had taught them that dismissing skilled 
workers during a temporary downturn can lead to severe skill shortages when demand recovers. This is particularly true in situations of imminent demographic change which result in smaller cohorts of young workers entering the labour market. In fact, there is evidence that those sectors in which firms had experienced difficulties in recruiting before the crisis were most affected by the crisis and employers were most reluctant to dismiss workers at short notice (Möller 2009). Furthermore, as routine manual tasks had been allocated to temporary agency work to a significant extent, manufacturing employers could terminate a substantial part of these contracts on short notice as well as not renew some fixed-term jobs (Hohendanner 2010). Hence, the secondary segment of agency workers had to bear a major part of the external adjustment during the crisis - but with the subsequent recovery employment in agency work picked up again quickly as shown in Table 2. Later on, stimulated by external demand, also regular employment in manufacturing started to increase again.

Long-term restructuring in manufacturing obviously contributed to achieve a good fit with the economic environment that is currently working well. Reducing the depth of the value chain in core businesses, while focussing on the most innovative parts, more outsourcing and a longer supply chain, both national and global, can explain this together with the increased flexibility of employment relations both with the core labour force and the marginal segment. 
Table 2: Labour Market Developments, 2007-2012

\begin{tabular}{|c|c|c|c|c|c|c|}
\hline & 2007 & 2008 & 2009 & 2010 & 2011 & $\begin{array}{l}2012 \text { (medium } \\
\text { IAB scenario) }\end{array}$ \\
\hline Real GDP, \% & +3.3 & +1.1 & -5.1 & +3.7 & $+3,0$ & +1.1 \\
\hline $\begin{array}{l}\text { Productivity change per } \\
\text { hour worked, } \%\end{array}$ & +1.7 & -0.1 & -2.5 & +1.4 & +1.3 & +0.3 \\
\hline Hours worked, \% & +1.6 & +1.2 & -2.7 & +2.3 & +1.7 & +0.8 \\
\hline Total employment, \% & +1.7 & +1.2 & +0.0 & +0.5 & +1.3 & +1.1 \\
\hline Total employment, 1,000 & 39,857 & 40,345 & 40,362 & 40,553 & 41,100 & 41,551 \\
\hline $\begin{array}{l}\text { Employees covered by social } \\
\text { insurance, } 1,000\end{array}$ & 26.943 & 27.510 & 27.493 & 27.756 & 28.431 & 28.942 \\
\hline $\begin{array}{l}\text { Employees covered by social } \\
\text { insurance, } \%\end{array}$ & +2.2 & +2.1 & -0.1 & +1.0 & $+2,4$ & +1.8 \\
\hline Unemployment, 1,000 & 3,760 & 3,258 & 3,415 & 3,238 & 2,976 & 2,843 \\
\hline Unemployment rate, \% & 9.0 & 7.8 & 8.2 & 7.7 & 7.1 & 6.8 \\
\hline $\begin{array}{l}\text { Temporary agency workers } \\
\text { in } 1,000\end{array}$ & 614 & 612 & 560 & 742 & n.a. & n.a. \\
\hline Short-time workers, 1,000 & 68 & 101 & 1,144 & 503 & 152 & 140 \\
\hline $\begin{array}{l}\text { Employment in } \\
\text { manufacturing, 1,000 }\end{array}$ & - & 7,638 & 7,420 & 7,287 & 7,421 & 7,494 \\
\hline
\end{tabular}

Source: Federal Statistical Office, Federal Employment Agency, Fuchs et al. 2012. 


\subsection{SERVICES}

The service sector used to be perceived as the Archilles' heel of the German employment model. Yet, the record levels of employment (and unemployment decline) achieved over the last year cannot be explained without taking service sector job creation seriously. And about 75 per cent of all jobs in Germany are now in services. In fact, while in the long-term perspective manufacturing jobs have shrunk (or stabilised at best), substantial employment gains occurred almost exclusively in services. Hence, understanding the recent expansion of the service sector in Germany is crucial.

In contrast to a perspective that sees services as a (mostly flexible and cheap) supply for manufacturing, the bulk of service sector jobs emerged in areas that are quite remote from manufacturing firms' demand. While it is true that business-related services expanded, household-related and social services were major components of job creation in recent years. Hence, service work cannot primarily be seen as an input or annex to manufacturing. Clearly, some outsourcing from manufacturing occurred, in particular in auxiliary services such as canteens, logistics, and in the area of temporary agency work which, in statistical terms, belongs to business services. But this is only one part of the service sector, not necessarily the largest one.

How can this be explained? As with manufacturing, the accelerated expansion of service sector employment has to be attributed to a longer sequence of restructuring. However, the major driving forces are different from those found in manufacturing. First, major parts of the service sector face increasing demand not by external clients on world markets but due to socioeconomic and demographic change, i.e. higher female labour market participation and population ageing in particular. Higher female labour market participation is responsible for additional labour supply available mostly for service sector jobs, and at the same time this generates demand for services to households. In addition, public policies play a crucial role, not only in terms of regulation, but also in terms of public (co)funding. This helps explain the growth of employment in health care, child care, education and research - while classical public administration has been stagnant at best.

Second, with respect to the private service sector, there is a more prominent role of labour market regulation governing the flexibility of employment relationships in particular in these occupations. In general, the private service sector tends to rely more on flexibility achieved via fixed-term contracts, self-employment or (marginal) part-time work than manufacturing as general skills tend to be more important, and firms are usually smaller. Hence, labour market de-regulation tends to affect private service sector companies and employees more directly. In addition, outside the public sector, collective bargaining coverage tends to be lower in many segments of the service sector compared to manufacturing so that wage dispersion tends to be higher (see, e.g. Dustmann, Ludsteck and Schönberg 2009), also amongst full-time workers (Figure 5). 
Figure 5: Wage dispersion, 1999 and 2009, full-time workers

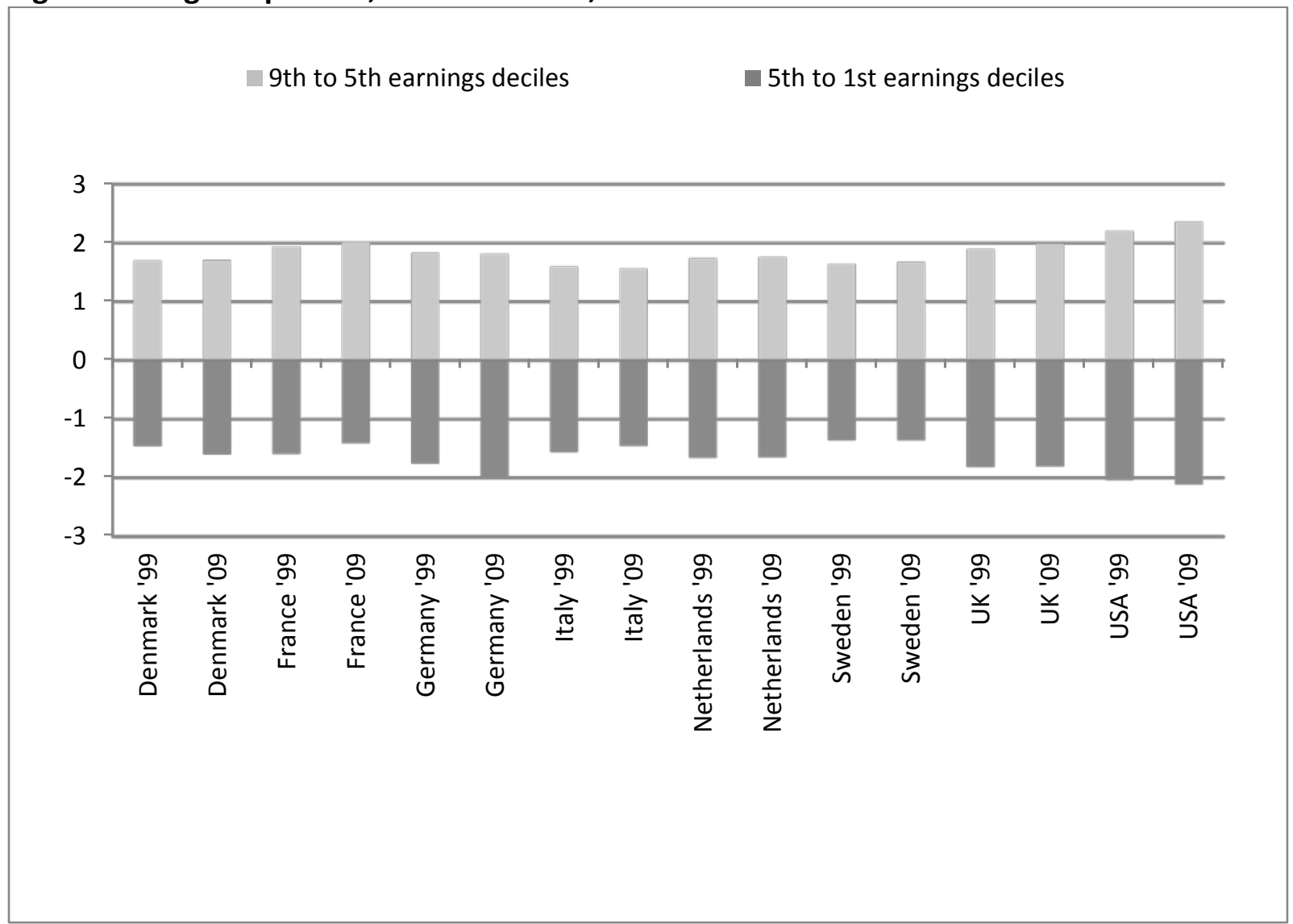

\section{Source: OECD Employment Outlook.}

Yet, despite the fact that strong attention in policy-making and academic research is certainly paid to the flexible or more 'precarious' part of the service sector, it would be misleading to argue that the private service sector has only created 'bad jobs'. In fact, the share of highly-paid jobs integrated into core labour market institutions such as collectively agreed wages, full social protection and dismissal protection is significant, in particular in highly qualified and specialised business-oriented or financial services. Strong growth of employment in services occurs at different levels of skills, pay and employment stability. Despite this, the expansion of the service sector drove the overall increase in the share of low pay (Kalina and Weinkopf 2012) and non-standard forms of employment in Germany - as a deregulated margin of the labour market in terms of employment protection and wage flexibility allowed for this reaction.

While it is true that the German labour market has become more flexible at the margin, i.e. in the area of non-standard employment, which is particularly relevant for services, attention has to be paid to the fact that most deregulation of employment occurred before service sector growth took off. In fact, changing conditions of demand and supply play a crucial role in translating institutional opportunities into actual labour market dynamics. Government-induced flexibility via deregulation can set crucial preconditions for job creation, but take-up was not 
immediate as it has to fit with actors' preferences. While service sector growth is a longstanding general trend in mature economies, job creation in Germany accelerated later than elsewhere, but obviously the institutional setting in Germany allows for more dynamism than expected in earlier times, in particular in the late 1990s.

Many areas of service sector employment rely more on the options for flexible contracts offered by the legislative framework than (skilled) manufacturing as Table 1 above has shown. However, there is also a prominent role of actors' behaviour in using and reshaping these options. This is particularly notable in marginal part-time work. Non-standard work has been liberalised over most of the period, and work incentives have been strengthened in particular for long-term unemployed and low-skilled workers by the Hartz reform package. But the system established in mid-2005 also created strong incentives for only partial, but flexible labour supply. While substantial part-time work was mainly unaffected by institutional changes (with continued reliance on joint taxation and a family-centred public old-age pension system), marginal part-time work was more an issue of institutional remodelling and grew dynamically in importance as a peculiar employment model. Marginal part-time work has been available for a long time but it was only discovered as a major employment option in some service occupations such as restaurants, retail trade or cleaning in the 1980s and 1990s with corresponding (female and migrant) labour supply. For married women and other groups of workers with supplementary income from other sources such as pensions marginal part-time is an attractive option to earn a supplementary income from work without deduction of taxes and social contributions - and for employers marginal part-time workers are a flexible category of workers regarding working time allocation and their willingness to accept low hourly pay, in particular after the last reform which raised the earnings threshold from 325 to 400 EUR per month and abolished the maximum working time limit of 15 hours per week. Marginal parttime is now a major employment arrangement in low- and medium-skilled routine services such as retail, cleaning and the hospitality sector.

Furthermore, also in a somewhat unintended manner, the option to combine minimum income support from the 'Hartz IV' scheme with earned income sets strong incentives for benefit recipients to take up work up to a about 160 EUR per month or 8 to 10 hours per week to maximise the benefits from the newly established earnings-disregard clause. Taking up marginal part-time work is a way to avoid further activation and to receive earnings that can only be raised further by a huge increase of working time or wages as marginal taxation is very high. This option of combining work and minimum income support has seen an unexpected rise in take-up. Now, by about 1.3 million workers can be defined as 'working unemployed', about half of them in marginal part-time work. There is also some evidence that some employers use this option to hire workers at low hourly wages assuming they can top up low pay with social benefits. Again, agency workers are overrepresented amongst full-time workers combining earned income from work and receipt of income support (Bruckmeier, Graf and Rudolph 2007). 


\section{A new equilibrium?}

After a protracted period of change the German employment system is fundamentally different from the situation in a typical 'welfare without work' context. With the recalibration of the German labour market and production model - not in an ideal, but second best manner Germany could overcome mass unemployment, the persistent Achilles' heel of the 1980s and 1990s, to a considerable degree and has generated continuous employment growth over the last 5 years, even in a situation of crisis when other countries saw massive job cuts. For the time being, however, Germany seems to have found an arrangement that makes the most out of given and adapted institutional settings. The current arrangement seems to fit with the economic environment so that a better performance can be achieved in comparison to the situation some 10 to 15 years ago. Clearly, compared to that period, market mechanisms have become stronger, and the 'buffering' role of law or collective agreements is more limited.

Regarding the core of export-oriented manufacturing, companies have redrawn their boundaries and reorganised the division between their core staff and the marginal labour force and between workers on standard contracts and those with non-standard contracts. At the same time, there is now a stronger role of subcontracting and national as well as international supply chains. The 'purified' core of those firms is characterised - and stabilised - by an elaborate arrangement of working time flexibility and rather flexible remuneration policies within collective agreements. Co-management by works councils is crucial here as is managed decentralisation of collective bargaining and more flexible collective agreements (regarding working time and wages). Hence, quite surprisingly against the background of earlier debates many features that were seen as rigid or outdated some 10 years ago are currently reappraised: dual vocational training is still an effective instrument to ensure smooth transitions from school to work and to provide skilled labour; collective bargaining has been modernised and stabilised successfully via strong internal flexibility which has made the German manufacturing competitive again; co-determination and co-management help stabilise the productive core, which also benefited from the use of publicly subsidised short-time work scheme, so with hindsight this is seen as a superior response to the crisis than to rely mostly on mainly external flexibility. Together with many 'good jobs' in services, there is now a remarkable stability regarding the overall figures of open-ended full-time employment which continue to represent about 60 per cent of all jobs. Wage moderation and internal flexibility have brought crowding out by flexible contracts in major parts in the economy to a halt.

Hence, there are obvious benefits and trade-offs for different categories of workers. Regarding the skilled core labour force in manufacturing, but also service sector occupations, neither employment stability nor the pay level has deteriorated. So working time flexibility, organisational reshuffling and more flexible and moderated wage setting has contributed to the robust existence of these jobs that are crucial for the performance of highly productive firms. Yet, work intensification and performance pressure has increased. The marginal work force faces a different situation: entry into the labour market, in particular into some specific categories of flexible employment has become easier over time, due to, first, deregulation of those types of employment, and second, increased availability of such jobs given structural 
change and employers' adjustment. Of course, pay and employment stability are less favourable in this case, and indirectly the marginal work force puts pressure on those core member of the labour force that can in principle be replaced. One should not neglect the fact, however, that most employees live in couple households. Stagnating wages in the main job (full-time, often male) could be offset by expanding labour supply (often part-time, mostly female) so that, despite some subjective discontent, in the aggregate figures the medium stratum of society ("Mittelschicht") appears remarkably stable with respect to its income situation (Grabka and Frick 2008). Still, a more substantial labour market integration of women is hampered by lack of external care services and high marginal taxation.

But, all in all, the risks of labour market flexibility are not distributed equally as some have more external flexibility (i.e. oftentimes unstable jobs) and wage risks to bear while those on permanent contracts benefit from fine-tuned models of internal flexibility resulting in strong job stability in exchange with some concessions regarding wage developments and working time intensification. And there continues to be some competitive pressure on the core stemming from flexible jobs. Policies to deregulate the margin of the labour market - and activation policies, at least to some extent - have opened up a segment of cheaper and more flexible types of work, in particular agency work, fixed-term employment, freelance and parttime, most notably marginal part-time work. Job growth in the service sector can to some extent be attributed to the increased external flexibility of this partial labour market. But not all developments can be explained by institutional change as there is also a strong occupational logic of sectoral and labour market change as well as specific forms of labour supply in these areas. Yet, with some simplification one can say that many of these jobs are highly flexible and constitute a quasi-liberal part of the labour market with very limited restrictions in terms of employment stability and pay, in particular in areas where there is strong employer power and skill requirements encouraging longer tenure are of very limited importance. About 20 per cent of German employees receive low pay, about 2 per cent work with temporary work agencies and 8 per cent have fixed-term contracts. Furthermore, about 12 per cent of all employees work in marginal part-time.

This is probably not the end of the story, however. We can expect economic restructuring to go on, along with a further expansion of market mechanisms in order to cope with the global economic environment under constant change and setting strong competitive pressure on German exporters. Furthermore, there is an uneasy divide between occupations and jobs in terms of working conditions and professional pathways. We can expect more prominent differences in terms of working conditions between the general labour market and occupations where labour supply is scarce, and at the same time the societal and political tolerance of 'precarious' forms of employment may be limited.

While this flexible, but segmented or dualised arrangement seems quite efficient and effective in stimulating employment growth and reducing registered unemployment, growing concern has been raised regarding the increase in inequality on the labour market and with respect to household incomes. Equity concerns are a sensitive issue in a Continental European context with a traditionally strong emphasis on a 'fair' distribution of economic gains. Together with 
continued sectoral and occupational change and business restructuring we cannot expect this constellation to remain stable in its current state. There are both tendencies to reduce the gap between core and margin as well as factors deepening it. Hence, while the dualised pattern of employment in Germany is probably here to stay, there is some dynamism in both segments as well as regarding the redefinition of the segmenting line.

First, current and expected skills shortages will rather accentuate the differentiation between skilled core workforces and workers on flexible contracts or in the low pay sector. We can observe a marked improvement of entry wages of graduates in shortage occupations and stronger initiatives of employers to recruit and retain skilled workers - and to make compromises regarding family-friendly working time etc. This does not hold for routine occupations, however, where labour supply is less limited. There, we rather see further tendencies to shift employment risks on workers, in particular on more vulnerable job market entrants, via larger shares of fixed-term hirings or expanding (at least initial) employment via agency work or low pay. However, as in the past, de- and re-regulation might be on the agenda either simultaneously or in a subsequent manner.

Second, and in contrast, there is currently stronger attention to equity considerations. In a situation with many more, but also more unequal jobs than in the past, low pay and other forms of allegedly 'precarious' work such as agency contracts have moved into the focus of the policy discourse. While on the one hand the business community and some parties are interested in expanding or at least maintaining the current set of non-standard jobs, trade unions and Social Democrats (and some Christian Democrats) would like to curtail it significantly. The widespread uneasiness with a quasi-liberal segment of the labour market has already motivated some partial re-regulation of the labour market. Over the last years, in a number of service sectors collectively agreed minimum wages have been made generally binding while there was no consensus on a national minimum wage. This affects sectors with bargaining coverage of at least 50 per cent such as old-age care, cleaning, waste removal, laundry services and security as well as the agency work sector. It is notable that these new minimum wages were implemented using a law from the mid-1990s which was first introduced to establish a generally binding minimum wage in the construction sector where, at that time, employers and trade unions feared competition from service providers based in other EU member states. Furthermore, there is some tendency to close the gap in working conditions, in particular pay, between agency workers and permanent staff, e.g. by requiring equal treatment after some period of assignment. Yet, no agreement could be reached on this. But it has become a topic of collective bargaining. Recently, in the metal working sector employers and trade unions agreed on granting extra pay after some duration of employment in the sector, hence brining agency staff closer to permanent employees of user companies. Regarding marginal part-time there is no clear strategy to limit its use but rather a tendency to slightly expand the scope of these jobs by lifting the earnings threshold from 400 to $450 \mathrm{EUR}$. Reregulating the margin of the labour market will certainly trigger a new round of adaptive behaviour of actors. 


\section{Conclusion}

The German labour market underwent a fundamental transformation over the last two decades. However, while much attention is paid to labour market reforms, in particular liberalisation of non-standard employment and activation policies, the role of micro-level adaptation of actors on the labour market is a necessary element in explaining change in employment outcomes. While changes both at the level of general public policies and at the level of individual companies or sectors need time to generate substantial effects, at some point a pattern of quite effective solutions may emerge that fits the current economic environment. This seems to be case with the German labour market and political economy now. In this sense, the adjustment capacities of government, the social partners and companies seem to be stronger and more powerful than expected in the late 1990s or the early 2000s when the German model was perceived as trapped in persistent mass unemployment and weak growth. Internal flexibility regarding working time and wages in areas with strong bargaining capacities was complemented and supported by a dynamic service sector relying partly on different patterns of flexibility, some of them set by legislative provisions. The longer-term perspective shows that public policies only had a limited influence on actual restructuring and employment creation, and cumulative change observed in Germany also shows that significant remodelling can be achieved without systematic coordination or a long-term political strategy or a big societal and political deal observed in corporatist countries. While the current pattern of labour market flexibility seems viable for the time being, we cannot expect institutional stability as such. Rather, the German labour market and the economy are undergoing further remodelling. Given the interactive role of policy making and market actors' behaviour we can expect further iterative adjustment in the foreseeable future. And one does not necessarily have to pessimistic about this. 


\section{References}

Baumgarten, D. et al. (2012). ,Herausforderung Zeitarbeit'. Studie im Auftrag der Bertelsmann Stiftung. Gütersloh.

Bellmann, L., Fischer, G. and Hohendanner, C. (2009). 'Betriebliche Dynamik und Flexibilität auf dem deutschen Arbeitsmarkt'. Handbuch Arbeitsmarkt 2009, 359-401.

Bruckmeier, K., Graf, T., Rudolph, H. (2007). ,Erwerbstätige Leistungsbezieher im SGB II: Aufstocker bedürftig trotz Arbeit', IAB Kurzbericht 22/2007.

Caliendo, M. (2009). 'Income Support Systems, Labor Market Policies and Labor Supply: The German Experience'. IFAU Working Paper 2009/26.

Carlin, W., Soskice, D. (2009). 'German economic performance: Disentangling the role of supply-side reforms, macroeconomic policy and coordinated economy institutions', Socio-Economic Review 7 (1), 67-99.

Dustmann, C., Ludsteck, J., Schönberg, U. (2009). ,Revisting the German Wage Structure', Quarterly Journal of Economics 124 (2): 843-888.

Ebbinghaus, B., Eichhorst, W. (2009). 'Employment Regulation and Labor Market Policy in Germany, 1991-2005'. In P. De Beer and T. Schils (eds.), The Labour Market Triangle Employment Protection, Unemployment Compensation and Activation in Europe. Cheltenham: Elgar, pp. 19-144.

Eichhorst, W., Grienberger-Zingerle, M., Konle-Seidl, R. (2008) ,Activation Policies in Germany: from Status Protection to Basic Income Support'. In: W. Eichhorst, O. Kaufmann and R. Konle-Seidl (eds.), Bringing the Jobless into Work? Berlin: Springer, pp. 17-67.

Eichhorst, W., Marx, P. (2011). 'Reforming German Labor Market Institutions: A Dual Path to Flexibility'. Journal of European Social Policy, 21(1): 73-87.

Eichhorst, W. Marx, P. (2012). 'Whatever Works: Dualisation and the Service Economy in Bismarckian Welfare States'. In P. Emmenegger, S. Häusermann, B. Palier and M. Seeleib-Kaiser (eds.), The Age of Dualization, Oxford: OUP, pp. 73-99.

Eichhorst, W., Feil, M., Marx, P. (2010).'Crisis, what crisis? Patterns of adaptation in European labor markets'. In K.F. Zimmermann and C. Wey (eds), The economy, crises and the labor market: can institutions serve as a protective shield for employment?. Berlin: Duncker and Humblot, pp. 29-57.

Eichhorst, W., Marx, P. and Tobsch, V. (2009). 'Institutional Arrangements, Employment Performance and the Quality of Work'. IZA Discussion Paper, 4595.

Fuchs, J. et al. (2012). ,Arbeitsmarktprognose 2012: Der Aufwärtstrend flacht ab’IAB Kurzbericht 3/2012.

Grabka, M.M., Frick, J.R. (2008). ,Schrumpfende Mittelschicht: Anzeichen einer dauerhaften Polarisierung der verfügbaren Einkommen?'DIW Wochenbericht 75 (10), 101-108.

Grömling, M., Matthes, J. (2010). 'Wächst die deutsche Industrie nur durch den Export?' Wirtschaftswissenschaftliche Beiträge des Lehrstuhls für Volkswirtschaftslehre, Wirtschaftsordnung und Sozialpolitik, Universität Würzburg, 110.

Hassel, A. (2011). 'The paradox of liberalization - Understanding dualism and the recovery of the German political economy'. LSE Europe in Question Discussion Paper, 42/2011. 
Hemerijck, A., Eichhorst, W. (2010). 'Whatever Happened to the Bismarckian Welfare State? From Labor Shedding to Employment-Friendly Reforms'. In B. Palier (ed.), A long good-bye to Bismarck. Amsterdam: AUP, 2010, pp. 301-332.

Hohendanner, C. (2010). 'Unsichere Zeiten, unsichere Verträge? Befristete Arbeitsverträgez wischen Auf- und Abschwung'. IAB Kurzbericht 14/2010.

Holst, H., Nachtwey, O.and Dörre, K. (2009). 'Funktionswandel von Leiharbeit. Neue Nutzungsstrategien und ihre arbeits- und mitbestimmungspolitischen Folgen'. Studie im Auftrag der Otto Brenner Stiftung. Frankfurt: Otto Brenner Stiftung.

Kalina, T., Weinkopf, C. (2012). ,Niedriglohnbeschäftigung 2010: Fast jede/r Vierte arbeitet für Niedriglohn'. IAQ Report 2012/01.

Köhler, C., Preisendörfer, P. (1988). 'Innerbetriebliche Arbeitsmarktsegmentation in Form von Stammund Randbelegschaften', Mitteilungen aus der Arbeitsmarkt- und Berufsforschung, 21(2): 268-277.

Köhler, C., Sengenberger, W. (1983). Konjunktur und Personalanpassung. Betriebliche Beschäftigungspolitik in der deutschen und amerikanischen Automobilindustrie. Frankfurt: Campus.

Lehmer, F., Ziegler, K. (2010). Brückenfunktion der Leiharbeit: Zumindest ein schmaler Steg. IAB Kurzbericht 13/2010.

Möller, J. (2010). 'The German labor market response in the world recession: De-mystifying a miracle'. Zeitschrift für Arbeitsmarktforschung, 42(4): 325-336.

Manow, P., Seils, E. (2000). 'Adjusting Badly: The German Welfare State, Structural Change, and the Open Economy'. In F. W. Scharpf and V. A. Schmidt (eds.), Welfare and Work in the Open Economy. Diverse Response to Common Challenges. Oxford, pp.264-307.

Palier, B., Thelen, K. (2010). 'Institutionalizing Dualism: Complementarities and Change in France and Germany', Politics and Society, 38(1):119-148.

Rehder, B.(2003). Betriebliche Bündnisse für Arbeit in Deutschland: Flächentarif und Mitbestimmung im Wandel, Frankfurt.

Rinne, U., Zimmermann, K. F. (2011). 'Another Economic Miracle? The German Labor Market and the Great Recession'. IZA Discussion Paper 6250.

Sachverständigenrat für die Begutachtung der gesamtwirtschaftlichen Entwicklung (2004). Jahresgutachten 2004/05.

Scharpf, F. W. (1991). Crisis and Choice in European Social Democracy. Ithaca: Cornell University Press.

Scharpf, F. W. (2000). 'Economic Changes, Vulnerabilities, and Institutional Capabilities'. In F. W. Scharpf and V. A. Schmidt (eds.), Welfare and Work in the Open Economy. Vol. 1: From Vulnerability to Competitiveness. Oxford: Oxford University Press, pp. 21-124.

Spermann, A. (2011). 'The New Role of Temporary Agency Work in Germany'. IZA Discussion Paper, 6180.

Streeck, W. (2009). 'Re-Forming Capitalism: institutional change in the German political economy', Oxford. 
Streeck, W.,Thelen, K. (2005). 'Introduction: Institutional Change in Advanced Political Economies'. In W. Streeck and K. Thelen (eds.), Beyond Continuity. Institutional Change in Advanced Political Economies. Oxford, pp. 1-39.

Trinczek, R. (1998). 'Arbeitszeitflexibilisierung in der bundesdeutschen Metallindustrie'. In H. G. Zilian and J. Flecker (eds.), Flexibilisierung - Problem oder Lösung?. Berlin: Edition Sigma, pp. 67-87. 